Proceedings of the 2018 International Scientific Conference 'Economic Sciences for Agribusiness and Rural Economy' No 2, Warsaw, 7-8 June 2018, pp. 319-325

\title{
WELL-BEING AS EXPERIENCED IN THE CONTEXT OF AN ORGANISATION AND MOTIVATION TO IMPROVE PROFESSIONAL QUALIFICATIONS
}

\author{
Sylwia Gołąb, $\mathrm{PhD}^{1}$; Beata Będzik, $\mathrm{PhD}^{2}$ \\ Faculty of Economics, West Pomeranian University of Technology
}

\begin{abstract}
The study aims to clarify the relationship between well-being at work and motivation to undertake additional learning activities. It was conducted among 96 professionally active individuals, students of Bachelor's and supplementary Master's degree studies with majors in Economics and Management as well as Master's degree students having an Individual Course of Studies majoring in Psychology. The hypotheses have been verified using: the Well-being in the Workplace Questionnaire by Czerw (2017), the Job Satisfaction questionnaire by Bajcar et al. (2011) and an original questionnaire of activity and motivation in the field of learning. The study results indicate that there is a relationship between certain dimensions of well-being at work and motivation to undertake additional learning activities.
\end{abstract}

Keywords: well-being at work, job satisfaction, undertaking training

JEL codes: R21, R22

\section{INTRODUCTION}

The studies relating to job satisfaction in the context of undertaken training courses are few and far between. So far, the studies that have been carried out in Poland focused mainly on the significance of personality conditioning (Laguna, 2012a), as well as job and life satisfaction (Laguna, 2012a), but they did not take into account the factors connected to the context of work ${ }^{3}$.

It is worthwhile to emphasise that job satisfaction can be both an effect of undertaking training and a factor that motivates to do it (Laguna, 2012b). This is particularly important because, as it has been observed, along with the socio-economic development the qualifications and competences of the employees are becoming obsolete, while various forms of further training are conducive to ensuring an appropriate level of knowledge and skills. Therefore, it is important to explain the relations between the well-being at a company and the motivation to undertake additional educational activity. This is the aim of the study.

\footnotetext{
${ }^{1}$ Corresponding author: Żołnierska 47, Szczecin, Poland, sylwia.golab@zut.pl, +4891 4496919

${ }^{2}$ Corresponding author: Żołnierska 47, Szczecin, Poland, beata.bedzik@zut.pl, +4891 4496994

${ }^{3}$ An interesting proposition of handling motivation when participating in trainings is the concept presented by M. Łaguna, who says that the participation in self-developing activities is a process connected with the realization of subsequent stages of the established goal.
} 


\section{THEORETICAL FOUNDATIONS}

Similarly to general well-being, the well-being at work can be considered in both hedonic and eudaimonic terms (Czerw, 2017). In the hedonic paradigm, the satisfaction with life is mainly caused by the degree of assessments made in the cognitive dimension that concern individuals' own life, and in the emotional dimension - that concerns emotions and moods experienced in their lives (Krok, 2013). It should be added that in the hedonic perspective, in addition to emotions and satisfaction, the declared level of perceived job stress or the level of job burnout are quite often used as indicators of well-being. This approach is not consistent, however, with the assumptions of positive psychology (Czerw, 2017).

An important and generally perceived research perspective of well-being at work is the emotional approach. Many researchers argue that emotions should be studied independently of one another, because they can only be derived from the perception of factors related to cognitive aspects. While considering the emotional approach, it is worthwhile to pay attention, among other things, to the applicable rating scales (cf. Hoppock Job Satisfaction Blank, Minnesota Satisfaction Questionnaire, European Social Survey), which as such can reflect some feelings (Wudarzewski, 2013). Just like in the other contexts of human functioning, work-related emotions are a source of motivation, activation, organisation and maintenance of employees' specific behaviours. These behaviours may be conducive to effective performance of tasks, but may also have a negative dimension - they may decrease efficiency at the workplace (Czerw, 2017).

Apart from emotions, the hedonic perspective of well-being at work also identifies job satisfaction. Being satisfied and the perception of job satisfaction translate not only into effectiveness of an employee but also into broadly defined quality of life. After all people spend a significant portion of their day in the workplace, while thanks the received pay gives them a chance to satisfy their various needs associated with their everyday functioning. The quality of work should, therefore, go hand in hand with the quality of life (Skrzypek, 2001).
It can be assumed that job satisfaction may be conducive to motivation to engage in undertaking activities aimed at improving the qualifications and extending the competences. An important element of division of motivation to achieve success (Elliot, 1996; after Franken, 2013) is the thesis that individuals are capable of self-regulation, thus they try to behave depending on their attitude to success. Individuals who want to strive for perfection and prove themselves undertake difficult tasks, thus developing their skills and the feeling of competence. Individuals who avoid proving themselves, avoid difficult tasks, which induces in them behaviours showing their high level of helplessness.

In the knowledge-based society, training is an effective and efficient method of individual improvement. Various forms of training support the implementation of individuals' own professional plans and tasks. Despite many opportunities for further training and the related benefits, not all professionally active or professionally passive individuals make use of them. Among the determinants of readiness to undertake training and broadly defined education, one can notice factors that determine the activity of individuals in this respect, such as e.g. demographic, motivation and personality variables. With respect to trainings, factors relating to work environment, i.e. those that are directly related to the situation in the workplace capable of determining decisions regarding further education, are gaining in important as well (Kawecka, Łaguna and Tabor, 2010). There are not many studies regarding the role of factors associated with the functioning of people at work, particularly those referring to the motivation to undertake trainings. The studies by Colquitt, LePine and Noe (2000) contributed significantly to the search for the conditions that motivate people to participate in trainings. Despite 20 years of working on this issue, they still point to the need for further analyses.

\section{MATERIALS AND METHODS}

Due to the limited volumetric framework of this publication, only one of many aspects of well-being at work were considered. The main purpose of the study is to explain correlation between well-being at 
work and motivation to undertake additional learning activities. The following detailed problems have been adopted within the main problem:

1. Is there any correlation between the eudaimonic and hedonic well-being at work and its particular dimensions, and motivation to improve professional qualifications measured by the number of undertaken training courses?

- H1.1. The higher the level of employees' wellbeing at work the higher their motivation to improve professional qualifications.

- H1.2. The higher the level of job satisfaction the higher the level of motivation for improving professional qualifications.

2. Is there any relationship between well-being at work and various types of further training?

- H2.1. The level of well-being at work positively correlates with undertaking all four types of training activities.

- H2.2. The level of job satisfaction negatively correlates with undertaking training activities at the request of the superior and positively correlates with undertaking training activities of employees' own volition.

3 . Is there a relationship between satisfaction with the chosen profession and undertaking additional learning activities?

- H3.1. There is a positive correlation between satisfaction with the chosen profession and undertaking all four types of additional learning activities.

The study ${ }^{4}$ was carried out among 96 professionally active individuals, students of Bachelor's and supplementary Master's degree studies with majors in Economics and Management as well as Master's degree students having an Individual Course of Studies majoring in Psychology. All the respondents were in the process of further learning. The average age of the respondents was 32 years, length of the period of service in the current company was 6 years, while total length was -10 years. The sample group was dominated by women, individuals with university education, non-managers, administrative employees (Table 1).

Table 1. Characteristics of the study sample

\begin{tabular}{|l|l|c|c|}
\hline \multicolumn{2}{|l|}{ Category } & $N$ & $\%$ \\
\hline \multirow{4}{*}{ Sex } & Women & 77 & 80.2 \\
\cline { 2 - 4 } & Men & 19 & 19.8 \\
\hline \multirow{5}{*}{ Education } & Managerial & 17 & 17.7 \\
\cline { 2 - 4 } & Non-managerial & 79 & 82.3 \\
\hline \multirow{5}{*}{ Type of position } & Secondary & 21 & 21.9 \\
\cline { 2 - 4 } & BA/BSc/Engineer & 31 & 32.3 \\
\cline { 2 - 4 } & University education & 44 & 45.8 \\
\hline & Administrative employee & 17 & 30.2 \\
\cline { 2 - 4 } & Customer service employee & 1 & 17.7 \\
\cline { 2 - 4 } & Production employee & 29 & 1.0 \\
\cline { 2 - 4 } & Specialist & 25 & 25 \\
\cline { 2 - 4 } & Other & 26 \\
\hline
\end{tabular}

Source: own work.

${ }^{4}$ The study was conducted between September 2017 and January 2018. 
The following have been used to verify the hypothesis: The Well-Being in the Workplace Questionnaire (KDMP) by Czerw (2017), the Job Satisfaction questionnaire by Bajcar et al. (2011) and an original questionnaire of activity and motivation in the field of further learning.

Statistical analyses required to verify the proposed hypotheses have been conducted using the IBM SPSS Statistics version 23. It has been used to calculate basic descriptive statistics of the analysed quantitative variables, test similarities between normal distribution and empirical distributions, and to conduct Pearson correlation analysis (r). A typical materiality threshold of $\mathrm{p}<0.05$ has been adopted.

\section{RESULTS AND DISCUSSION}

The Pearson correlation analysis has been carried out in order to verify the hypothesis concerning correlation between the level of employees' well-being at work and their motivation to improve professional qualifications. The analyses have shown that there is a statistically confirmed correlation between the number of training courses and the total job satisfaction. The higher the level of employees' well-being at work the higher their motivation to improve their professional qualifications. In the course of a detailed analysis, one can notice that there is a correlation between all the dimensions, except for Positive relationships with co-workers (Table 2).

Then the hypothesis concerning correlation between the level of job satisfaction and motivation to improve professional qualifications has been verified. The analysis has shown no correlation between job satisfaction and the number of undertaken training courses $(\mathrm{r}=0.195 ; \mathrm{p}>0.05)$, thus hypothesis 1.2 has not been confirmed.

The Pearson correlation analysis has been carried out in order to verify the hypothesis concerning correlation between the level of well-being at work and taking all four types of activities associated with further learning. The carried out analyses have shown a positive correlation between general level of wellbeing at work and work-related training courses and negative correlation with training courses not related to the currently held position. In the course of a detailed analysis, one can notice that there is a positive correlation between the dimension Adjustment and development and Positive organisation and undertaking training courses which are associated with the currently held position. There is a negative correlation between the dimension Adjustment and development and undertaking training courses which are not related to the performed work (Table 3).

The Pearson correlation test has been used to verify correlation between the level of job satisfaction and undertaking further learning activities at the request of the superior and of one's own volition. No correlation has been found between the general level of job satisfaction and undertaking activities aimed at improving qualifications, both at the request of the superior and of one's own volition. There is, however, a correlation between some dimensions of satisfaction and the analysed variables. Job satisfaction with reference to professional development is positively correlated with undertaking further learning activities of one's own volition. The second statistically confirmed correlation concerns job satisfaction with

Table 2. Correlation between employees' well-being and their motivation to improve professional qualifications $(N=96)$

\begin{tabular}{|l|c|c|c|c|c|}
\hline Specification & $\begin{array}{c}\text { Positive } \\
\text { organisation }\end{array}$ & $\begin{array}{c}\text { Adjustment and } \\
\text { development }\end{array}$ & $\begin{array}{c}\text { Positive } \\
\text { relationships with } \\
\text { co-workers }\end{array}$ & $\begin{array}{c}\text { Contribution to } \\
\text { the organisation }\end{array}$ & $\begin{array}{c}\text { Well-being in } \\
\text { the Workplace } \\
\text { Questionnaire } \\
\text { (KDMP) }\end{array}$ \\
\hline $\begin{array}{l}\text { Training courses } \\
\text { number }\end{array}$ & $0.217^{*}$ & $0.228^{*}$ & 0.115 & $0.185^{*}$ & $0.239^{*}$ \\
\hline
\end{tabular}

*Correlation is significant at the 0.05 level (2-tailed).

Source: own studies. 
Proceedings of the 2018 International Scientific Conference 'Economic Sciences for Agribusiness and Rural Economy' No 2, Warsaw, 7-8 June 2018, pp. 319-325

Table 3. Correlation between well-being in the workplace and various types of further learning $(N=96)$

\begin{tabular}{|l|c|c|c|c|c|}
\hline Specification & Positive \\
organisation & $\begin{array}{c}\text { Adjustment } \\
\text { and } \\
\text { development }\end{array}$ & $\begin{array}{c}\text { Positive } \\
\text { relationships } \\
\text { with co-workers }\end{array}$ & $\begin{array}{c}\text { Contribution } \\
\text { to the } \\
\text { organisation }\end{array}$ & $\begin{array}{c}\text { Well-being } \\
\text { in the Workplace } \\
\text { Questionnaire } \\
\text { total (KDMP) }\end{array}$ \\
\hline $\begin{array}{l}\text { Training at the request } \\
\text { of the superior }\end{array}$ & -0.18 & -0.003 & -0.019 & -0.107 & -0.039 \\
\hline Training on a voluntary basis & 0.176 & 0.178 & 0.129 & 0.086 & 0.188 \\
\hline Work-related training & $0.216^{*}$ & $0.327^{* *}$ & 0.105 & 0.189 & $0.272^{* *}$ \\
\hline Non-work related training & -0.186 & $-0.247^{*}$ & -0.119 & -0.162 & $-0.230^{*}$ \\
\hline
\end{tabular}

*Correlation is significant at the 0.05 level (2-tailed); ${ }^{*}$ Correlation is significant at the 0.01 level (2-tailed).

Source: own studies.

Table 4. Correlation between job satisfaction and its dimensions, and the undertaking of further learning activities voluntarily or at the request of the superior $(N=96)$

\begin{tabular}{|l|c|c|}
\hline Specification & $\begin{array}{c}\text { Undertaking training } \\
\text { on a voluntary basis }\end{array}$ & $\begin{array}{c}\text { Undertaking training } \\
\text { at the request of the superior }\end{array}$ \\
\hline Colleagues & 0.118 & -0.042 \\
\hline Direct superiors & 0.074 & 0.014 \\
\hline Type of tasks performed at work & 0.121 & 0.021 \\
\hline Working conditions & 0.131 & -0.128 \\
\hline Professional development & $0.221^{*}$ & 0.012 \\
\hline Pay & 0.129 & 0.036 \\
\hline Work time & 0.092 & -0.137 \\
\hline Employment stability & -0.026 & $-0.267^{* *}$ \\
\hline Company/institution as a whole & 0.067 & -0.136 \\
\hline General job satisfaction & 0.146 & -0.099 \\
\hline
\end{tabular}

${ }^{*}$ Correlation is significant at the 0.05 level (2-tailed); ${ }^{* *}$ Correlation is significant at the 0.01 level (2-tailed).

Source: own studies.

reference to employment stability and undertaking training courses at the request of the superior - negative correlation (Table 4).

The Pearson correlation analyses have been carried out in order to verify the hypothesis concerning correlation between satisfaction with the chosen profession and undertaking all four types of additional activities. The carried out analyses have partially confirmed the hypothesis (3.1) concerning positive corre- lation between satisfaction with the chosen profession and undertaking all four types of additional activities. There is a statistically confirmed positive correlation between satisfaction with the chosen profession and undertaking training courses associated with the held position $(r=0.246 ; p<0.05)$. There is a negative correlation between satisfaction with pursuing the chosen profession and undertaking activities not related to the currently held job $(r=-0.302 ; \mathrm{p}<0.05)$. 


\section{CONCLUSIONS}

The results of the carried out research have shown that experiencing well-being at work may be connected with motivation to undertake additional learning activities. People who perceive their organisation as trustworthy, convinced that they are a part of this organisation and their activity contributes to its better functioning, more willingly undertake training courses. The results are similar to those achieved by Colquitt, LePine and Noe (2000). According to the researchers, the engagement and support of superiors can be the determining factor in employees' decisions to undertake trainings.

Being aware of one's own competences and predispositions, adequate to the held position and the assigned tasks, is also important. It therefore turns out that experiencing well-being at work can translate into positive attitude to training courses and be expressed in the number of undertaken courses. At the same time, the results of the study have also shown that there is no correlation between undertaking training courses and having friendly relationships with co-workers. This is understandable, because the feeling of trust between employees and having the certainty of getting help when in need concerns major aspects of functioning in the organisation and is not necessarily connected with personal development or improvement.

Of essential importance in the carried out analyses has been assessment of the motivation to improve professional qualifications that takes into account various types of further learning. Training courses are an integral part of any organisation as the importance of knowledge-based organisation is being emphasised more and more often. That is why, the correlations between well-being experienced in the workplace and various types of additionally undertaken learning activities have become interesting. The analyses have shown that people experiencing well-being at work and convinced of being at the right place are more willing to undertake training courses that are related to this work. It should also be emphasised that employees' perception of well-being is important not only from the point of view of themselves, but also the organization, due to the fact that improvement undertaken by the team members contributes to the de- velopment of their competences, and thus translates into increased efficiency.

In addition, the presented results show that people who are not satisfied with their current work more often choose training courses which are not related to the currently held position or organisation in which they are employed. This may result from their intention to change job or profession. Similar results have been obtained for satisfaction with the chosen profession. People satisfied with the chosen profession more willingly undertake training courses associated with the currently held position, while those dissatisfied - choose training courses not related to the performed work.

An interesting aspect of the carried out studies has been assessment of correlation between job satisfaction and its dimensions, and undertaking further learning activities voluntarily or at the request of the superior. Although no correlation has been observed between general level of job satisfaction and undertaking training courses, but there are correlations between some of its dimensions. On the basis of the results obtained, it can be assumed that people who feel a strong need for professional development, more often undertake training of their own volition. This is understandable as work and professional improvement constitute a natural need for many people. An interesting and statistically confirmed correlation is the one relating to employment stability and undertaking training at the request of the superior. It turns out that people who do not experience the feeling of safety identified with employment stability in a given organisation, more often undertake training at the request of the superior. It may be that those employees, for fear of losing their jobs, agree to any form of further learning proposed by their superiors, alternatively, their behaviour can be a form of pleasing their superiors in order to ensure for themselves a stable position in the company.

An important factor can be the seniority at a given company - employees with less time spent at a workplace may not be sure of their position in the organization and can be afraid to lose their jobs (Wojtczuk-Turek, 2010).

The reasons for the well-being at work should be searched for not only in the sphere of psychological 
competences or professional interests, but also in the organization's conditioning. Due to the many aspects of the discussed issue, it is necessary to carry out detailed studies in this field, taking into account both the psychological aspects that refer to the individual, as well as the factors connected to the company in which a given employee is operating. It would be interesting to explain the relation between forming a bond with an organization, the motivation to work, effective working or the organization's culture and the decisions to undertake activities that lead to the increase in professional competences.

It has to be highlighted that the analyses are only a fraction of the studies carried out by the author which focus on the widely understood well-being at work. The presented results, due to the size limitations of this publication, refer only to one of the many aspects of well-being at work, i.e. undertaking additional educational activity. In order to have the full scope of the relations between the well-being at work and the motivation to undertake additional educational activity, it would be necessary to consider other factors associated with trainings, different than the ones analysed in this study, such as the sources of funding, the availability of trainings or the size of the company. Despite these limitations, the results of the studies can be a hint to learn and understand the reasons for undertaking trainings, taking into consideration both personality conditioning as well as the context of work, which could possibly support the work of the company's management.

\section{REFERENCES}

1. Bajcar, B,. Borkowska, A., Czerw, A., Gąsiorowska A. (2011). Satysfakcja z pracy w zawodach z misja społeczną: psychologiczne uwarunkowania [Satisfaction from work in professions with a social mission: psychological conditioning]. Gdańskie Wydawnictwo Psychologiczne, Gdańsk.

2. Colquitt, J.A., LePine, J.A., Noe R.A. (2000). Toward an integrative theory of training motivation: A metaanalytic path analysis of 20 years of research. Journal of Applied Psychology, 85, pp. 678-707.

3. Czerw, A. (2017). Psychologiczny model dobrostanu w pracy. Wartość i sens pracy [Psychological model of well-being at work. Value and sense of work]. Wydawnictwo Naukowe PWN, Warszawa.

4. Franken, R. E. (2013). Psychologia motywacji [Psychology of motivation]. Gdańskie Wydawnictwo Psychologiczne, Gdańsk.

5. Kawecka, K., Laguna, M., Tabor, K. (2010). Gotowości do podejmowania szkoleń i dalszego kształcenia. Propozycja ujęcia teoretycznego i skal pomiaru [Readiness to undertake training and further education. Proposed theoretical approach and measurement scales]. Organizacja i Kierowanie, 2 (140), pp. 43-55.

6. Krok, D. (2013). Nadzieja jako predykator wymiarów dobrostanu psychicznego [Hope as a predictor of the dimensions of mental well-being]. Polskie Forum Psychologiczne, 18 (2), pp. 157-172.

7. Łaguna, M., Mielniczuk, E., Wuszt, E. (2015). Rola trzech wymiarów przywiązania do organizacji na różnych etapach procesu podejmowania szkoleń [The role of three dimensions of attachment to the organization at various stages of the training process]. Polskie Forum Psychologiczne, 20 (1), pp. 47-61.

8. Łaguna, M. (2012a). Cechy osobowości a podejmowanie działań rozwojowych przez pracowników [Personality traits and undertaking development activities by employees]. Czasopismo Psychologiczne, 18, pp. 277-285.

9. Łaguna, M. (2012b). Satysfakcja z życia i satysfakcja z pracy a motywacja do podejmowania szkoleń: doniesienie $\mathrm{z}$ badań [Satisfaction with life and job satisfaction and motivation to undertake training: report from research]. Psychologia Jakości Życia, 12 (2), pp. 163-172.

10. Skrzypek, E. (2001). Czynniki kształtujące jakość życia [Factors shaping the quality of life]. In: Lewandowski, J., Lecewicz-Bartoszewska, J. (ed.) Ergonomia niepełnosprawnym - jakość życia [Ergonomics of the disabled - quality of life] Łódź: Wydawnictwo Politechniki Łódzkiej, Łódź, p. 239.

11. Wojtczuk-Turek, A. (2010). Osobowościowe predyktory zaangażowania pracowników - analizy empiryczne [Personality predictors of employee engagement - empirical analyzes]. Organizacja i Kierowanie, 2, pp. 21-41.

12. Wudarzewski, G. (2013). Satysfakcja z pracy - konceptualizacja pojęcia w świetle badań literaturowych [Satisfaction from work - conceptualization of the concept in the light of literature research]. Zeszyty Naukowe Wyższej Szkoły Bankowej we Wrocławiu, 5 (37), pp. 330-331. 